\title{
DIAGNOSIS AND PREVALENCE OF BACTERIAL VAGINOSIS IN A TERITIARY CARE CENTRE AT KANPUR"
}

Manju Nawani' ${ }^{1}$ R.Sujatha ${ }^{2}$.

1. Professor \& HOD, Department of Obstetrics \&Gynaecology, Rama Medical College Hospital \& Research Centre, Mandhana, Kanpur.

2. Associate Professor, Department of Microbiology, Rama Medical College Hospital \& Research Centre, Mandhana, Kanpur.

\section{CORRESPONDING AUTHOR:}

Dr.R. Sujatha,

No.16. $7^{\text {th }}$ Cross.

Cambridge Layout, Halasuru, Near Sai Baba Mandir,

Bangalore - 560008 .

Email-drsujatha152@gmail.com

ABSTRACT: Bacterial vaginosis is the most common vaginal infection in women of child bearing age. The aim of this study was to find the prevalence and the most reliable, cost effective diagnostic technique in order to prevent the complications such as miscarriage, development of PID, etc. METHODS: This is a prospective study carried out in Rama Medical College Hospital, Mandana, Kanpur by Gynaecology and Microbiology department. A total of 300 women with symptomatic vaginal discharge were examined for the diagnosis of Bacterial vaginosis. Age range of the patients was between 18-45 years. It was conducted over a period of four months from $1^{\text {st }}$ December 2012 to $1^{\text {st }}$ April 2013.These patients were then studied by rapid clinical tests i e Amsel's criteria, and by gram stain. RESULTS: Among the 300 patients with symptomatic vaginal discharge, 123(41\%) were diagnosed having bacterial vaginosis by Amsel criteria. Out of these 120(97.5\%) patients had homogenous milk like discharge, 112(91\%) had a positive whiff test, 121(98.3\%) had clue cells and 111[90\%] had ph>4.5. and 126 [42\%] were diagnosed by gram stain. CONCLUSIONS: Amsel's criteria are as good as gram stain as it is simple, easy, and cost effective and fast and reliable, and can be done in OPD which can be used for precise and fast treatment.

KEY WORDS: Bacterial Vaginosis, Amsel's criteria, Gram stain,

INTRODUCTION: Bacterial vaginosis is the most common vaginal infection in women of child bearing age (1).

Approximately $50-75 \%$ of women with bacterial vaginosis are asymptomatic $(2,3)$. The symptoms include excessive thin vaginal discharge which has milky white colour and unpleasant smell, but pruritis, erythema and inflammation are typically absent. Many patients of Bacterial vaginosis remain undiagnosed because self diagnosis and diagnosis by a physician is not reliable without laboratory tests. Diagnosis of Bacterial vaginosis is important for its serious complications such as premature rupture of membranes, miscarriage development of PID, increased risk of acquiring STD such as HIV and also increased genital tract HIV shedding (4) Prevalence of bacterial vaginosis varies with age, ethnicity and education and poverty(5). Among U.S, Europe and South 
East Asian countries prevalence varies from 5-50\%(6,7). Risk factors for Bacterial vaginosis include douching (8). Douching decreases lactobacilli thus facilitating Bacterial vaginosis associated bacteria (9).

The aim of this study was to find the prevalence and the most reliable, cost effective technique, for the diagnosis of Bacterial vaginosis and to prevent the complications in child bearing age group patients.

METHODS: It is a prospective study carried out by Gynaecology and Microbiology department in Rama Medical College Hospital, Mandhana, Kanpur. A total number of 300 patients attending in Gynae OPD with chief complaints of abnormal vaginal discharge were included in this study. The study was conducted over a period of four months from $1^{\text {st }}$ December 2012 to $1^{\text {st }}$ April 2013. The patients who had bleeding or recent abortion were excluded from the study because it would have altered the PH of vagina. The Hospital Ethical Committee approval was taken, and proper consent from the patient was taken, prior to the examination. The patients were asked to lie in lithotomy position for sterile speculum examination. A high vaginal swab stick was used to make two slides of secretions. To one slide few drops of normal saline were added and wet mount was studied under microscope for the presence of clue cells. Clue cells were identified as desquamated vaginal epithelial cells which were densely coated by adherent bacteria such that their borders were indistinct. The other slide was air dried and studied after gram staining. The stain showed mixed flora consisting predominantly curved gram negative or gram variable rods and or gardenella and bacteroides morphocytes, while lactobacilli were either typically absent or very few in number. Whiff test was done by placing few drops of $10 \% \mathrm{KOH}$ on the secretions and fishy odour was noted in the positive cases. Vaginal $\mathrm{pH}$ was tested by dipping the $\mathrm{pH}$ paper into secretion and the change in colour was noted.

Bacterial vaginosis cases were diagnosed using the presence of clue cells and two or more of the other three Amsel's criteria which includes Homogenous thin milky vaginal discharge, Positive Whiff test, $\mathrm{pH}>4.5$ (normal vaginal $\mathrm{PH} 3.8-4.2$ ).

RESULTS: A total of 300 women with symptomatic vaginal discharge were examined for the diagnosis of Bacterial Vaginosis (BV). Age range of the patients was between 18-45 years with mean (32.32+/-5.3yrs). Parity was from $0-7$ with mean of $(3.11+/-1.6) .0 n$ the basis of 3 out of 4 Amsel criteria 123(41\%) patients were confirmed as BV. Out of these $120(97.5 \%)$ patients had homogenous milk like discharge, 112(91\%) had a positive whiff test, 121(98.3\%) had clue cells and $111[90 \%]$ had pH.4.5. and 126 [42\%] were confirmed as BV by gram stain.

TABLE I: Number of patients with bacterial vaginosis diagnosed by Amsel's criteria (n=123)

\begin{tabular}{|l|l|}
\hline Amsel's criteria & No of patients(123) \\
\hline Homogenous milk like vaginal discharge & $120(97.5 \%)$ \\
\hline Whiff test & $112(91 \%)$ \\
\hline Clue cells & $121(98.3 \%)$ \\
\hline PH $>4.5$ & $111(90 \%)$ \\
\hline
\end{tabular}


TABLE II: Incidence of Bacterial Vaginosis by different tests(n=300)

\begin{tabular}{|l|l|}
\hline Test & Positive cases \\
\hline Amsel's criteria & $123(41 \%)$ \\
\hline Gram staining & $126(42 \%)$ \\
\hline
\end{tabular}

DISCUSSION: Bacterial vaginosis is the most frequent causes of vaginitis, and is characterized by increase in growth of anaerobic and aerobic microorganisms due to unbalanced eco-system in the vagina(10).The clinico-pathologic condition characterized by redness in the vaginal wall, bad-odour discharge and the presence of clue cells in cervicovaginal specimens, which results from the transformation of the acidic vaginal $\mathrm{pH}$ to an alkaline $\mathrm{pH}$ via metabolic activity of the afore defined bacteria is known as bacterial vaginosis (11).

Fast and reliable diagnosis of vaginitis lead to precise and fast treatment. A delay in diagnosing and, treating STDs can lead to chronic complications and irreversible sequelae. Women and Children suffer the main consequences. In women, the most serious consequences are acute and chronic pelvic inflammatory diseases, infertility, ectopic pregnancy, and cervical cancer. Infection during pregnancy may cause spontaneous abortion, stillbirth, prematurity, low birth weight, congenital syphilis, and ophthalmia neonatorum (12).Non-ulcerative STDs were risk factors for sexually transmission of HIV-1 in women, after controlling for sexual exposure. Because of their high prevalence in some population, non-ulcerative STD may represent a considerable populationattributable risk in transmission of HIV-1 worldwide. The identification of treatable STD as risk factor for HIV-1 transmission offers an important additional strategy for the prevention of HIV/AIDS (13)

The diagnosis of BV is based on clinical findings and laboratory testing. In clinical practice BV is diagnosed using Amsel's criteria (10) and in laboratory by gram stain which is probably the most reliable method and is used to differentiate BV from other vaginal infections (14).The overall prevalence of Bacterial vaginosis in this study was $41.5 \%$. Among the 300 patients $123(41 \%)$ were diagnosed having bacterial vaginosis by Amsel Criteria, i e 120(97.5\%) patients had homogenous milk like discharge, 112(91\%) had a positive whiff test, 121(98.3\%) had clue cells and 111[90\%] had ph>4.5., and 126 [42\%] were diagnosed by gram stain. The sensitivity of Amsel's criteria came out to be $97.6 \%$. The similar results are given by Gratco et al (16).Whenever clinical criteria is used the sensitivity reported from gram staining has ranged from $62-100 \%$ (17). However a definitive advantage of gram staining is that it is more objective as slide can be stored for future references. The main difficulty for the clinician is the lack of access to direct microscopy, hence it is advised that Amsel's criteria may be used for the diagnosis of BV at the OPD as it is simple, easy, and cost effective and fast and reliable.

CONCLUSION: Amsel's criteria are as good as gram stain as it is simple, easy, and cost effective and fast and reliable, and can be done in OPD which can be used for precise and fast treatment.

\section{REFERENCES:}


1. Rao P, Devi S, Shriyan A, Rajaram M, Jagdishchandra K. Diagnosis of bacterial vaginosis in rural set up: comparison of clinical algorithm, smear scoring and culture by semiquantitative technique. Indian J Med. Microbiol 2004; 22:47-50.

2. Schwebke JR, Hillier SL, Sobel JD. Validity of the vaginal gram stain for the diagnosis of bacterial vaginosis. Obstet Gynecol 1996; 88:573

3. Kent L. Epidemiology of vaginitis. Am J Obstet Gynecol1991; 165:1168

4. Sha BE, Zariffard MR. Wang QJ, Chen HY, Bremer J, Cohel MH, et al. Female genital tract HIV load correlates inversely with Lactobacillus species but positively with bacterial vaginosis and Mycoplasma hominis. J infect Dis 2005; 191:25-32.

5. Allsworth JE, Peipert JF. Prevalence of bacterial vaginosis. Obstet Gynecol 2007; 109:11420.

6. Weir E. Bacterial vaginosis: more questions than answers. Can Med Assoc J 2004; 171:448501.

7. Rahman S, Garland S, Carric M, Tabrigi SM, Rahman M, NesaK, et al. Prevalence of Mycoplasma genitalium in health clinical attendees complaining of vaginal discharge in Bangladesh. Int J STD AIDS 2008; 19:772-74.

8. Klebanoff MA, Schwebke JR, Zhang J, Nansel TR, Yu KF, Andrews WW. Vulvovaginal symptoms in women with bacterial vaginosis. Obstet Gynecol 2004; 104:267-72.

9. Zhang J, Hatch M, Zhang D, Shulman J, Haville E, Thomas AG. Frequency of douching and risk of bacterial vaginosis in African American women. Obstet Gynecol 2004; 104:756-60.

10. Amsel R, Totten PA, Spiegel CA, Chen KC, Eschenbach D, Holmes KK."Non specific vaginitis. Diagnostic criteria and microbial and epidemiologic associations"Am.J.Med.1983:74(1):1422

11. Priestly CJ, Kinghorn GR. Bacterial vaginosis.Br J Clin Pract 1996;50:331-4

12. Holmes KK MP, Sparling PF. Sexually transmitted diseases.2nd ed. New York: McGraw-Hill; 1990.

13. Laga M MA, Kivuvu M, Malele B, Tuliza M, Nzila N, Goeman J, Behets F, Batter V, Alary M, et al.Non ulcerative sexually transmitted diseases as risk factors for HIV-1 transmission in women: results from a cohort study. AIDS 1995;9(10):1202-3

14. Nugent RP, Krohn MA, Hiller SL. Reliability of diagnosing bacterial vaginosis is improved by a standardized method of gram stain interpretation. J Clin Microbiol 1991; 29:297.

15. Iftikhar R. Diagnosis of bacterial vaginosis by Amsel's Criteria. J Coll Physicians Surg Pak $2003 ; 13: 76-8$.

16. Grataco AE, Figueras F, Barranco M, Ros R, Andreu AA, Pedro L, Cararach AV. Prevalence of bacterial vaginosis and correlation of clinical to Gram stain diagnostic criteria in low risk pregnant women. European Journal of Epidemiology 1999; 15: 913-6.

17. Shahzadi Neelam, Irum Sohail. "Rapid Clinical Diagnostic Tests for Bacterial Vaginosis and its Predictive value" International Journal of Pathology; 2010; 8(2): 50-52. 